\title{
Immigration, obesity and labor market outcomes in the UK
}

Susan L Averett ${ }^{1 *}$, Laura M Argys ${ }^{2}$ and Jennifer L Kohn ${ }^{3}$

\author{
* Correspondence: \\ averetts@lafayette.edu \\ ${ }^{1}$ Lafayette College, Easton, PA, USA \\ Full list of author information is \\ available at the end of the article
}

\begin{abstract}
We estimate the dual effects of immigration and obesity on labor market outcomes in the UK using the British Household Panel Survey. We find support for the "healthy immigrant hypothesis" and evidence that immigrants' weights increase with time in the UK. While overweight and obese men enjoy a wage premium, overweight and obese immigrant men face a wage penalty and are less likely to work in a white collar job. Overweight immigrant women are substantially more likely to suffer work limitations. While data limitations preclude efforts to address endogeneity, these associations suggest that immigrants have not been spared from the obesity epidemic.

Keywords: Immigrant, Obesity, Labor market outcomes
\end{abstract}

\section{Introduction}

A large body of research suggests that immigrants are often substantially more productive and healthier than both natives in their host countries and non-migrators remaining in their countries of origin (e.g. Chiswick 1978; Borjas 1985, 1995; Park et al. 2009; Antecol and Bedard 2006; Kennedy et al. 2006). Despite likely productivity advantages, immigrants typically face a wage penalty upon entry to the host country. Studies suggest that poor English language ability and the possession of foreign qualifications make it difficult for immigrants to assimilate to the labor market of the host country (Trejo 1997; Friedberg 2000; Shields and Wheatley Price 2002). Over time, through investments in location specific human capital, immigrants tend to assimilate though their wages and employment do not always converge to those of natives (Chiswick 1978; Carliner 1980; Borjas 1985, 1995; Trejo 1997; Friedberg 2000).

Similarly, there is a consistent finding that immigrants tend to be healthier upon arrival to their new homes but eventually assimilate to the less healthy patterns of their host countries. This is often termed the healthy immigrant effect (e.g. Hao and Kim 2009; Antecol and Bedard 2006; McDonald and Kennedy 2005). Many of these studies focus on weight-related health outcomes and note that immigrants are less likely to be obese than their native-born counterparts. There is also a substantial literature on the link between obesity and labor market outcomes (see Averett 2011 for a review of this literature). The evidence from these studies is mixed as to whether or not the obese face wage and employment penalties in the labor market.

(C) 2012 Averett et al.; licensee Springer. This is an Open Access article distributed under the terms of the Creative Commons Attribution License (http://creativecommons.org/licenses/by/2.0), which permits unrestricted use, distribution, and reproduction in any medium, provided the original work is properly cited. 
Our objective is to explore the complex interactions among immigration, obesity and labor market outcomes ${ }^{1}$. We know of only one study to date that specifically examines the potential double penalty faced by obese immigrants in the labor market (Cawley et al. 2009). Specifically, Cawley, Han and Norton use a large US dataset comprised of immigrants from developing countries to examine the effect of Body Mass Index (hereafter BMI) and indicator variables for the clinical weight classifications for overweight and obese on several labor market outcomes ${ }^{2}$. They find few significant wage penalties except for obese female immigrants who have been in the country a short time.

Whereas most of the previous literature on immigrant health, wages, and assimilation has focused on immigrants to the US, our study uses data from a nationally representative dataset from the UK covering the period 2004 to 2006. We extend the Cawley et al. (2009) analysis in two ways. First we examine immigrants in a European country that has recently experienced substantial immigration. Second, we expand their analysis to compare immigrants with non-immigrants. The UK presents a different context to examine the effect of immigration and body weight on labor market outcomes because most immigrants to the UK are not from developing countries.

We find some significant associations between weight and labor market outcomes for immigrants. Our results indicate that immigrants overall do not fare poorly in the UK labor market, although, overweight and obese male immigrants face a wage penalty relative to both other immigrants and overweight and obese natives.

To set the stage for our analysis we begin with a brief overview of migration to the UK and a description of the labor market conditions faced by these immigrants. We follow this with a review of the relevant literature. Following the review of the literature we turn to our empirical analysis. We first describe the key features of our UK data set. Then we replicate the Cawley, Han and Norton models on a sample of immigrants only. Our data allows us to extend the work of Cawley, Han and Norton by directly comparing the experiences of immigrants and natives with respect to both weight and labor market outcomes. We conclude with policy implications and directions for future research.

\section{Migration and labor markets in the UK}

As measured by the gross inflow of migrants, currently the UK is the third most popular destination for immigrants worldwide, behind only the US and Germany (OECD $2011)^{3}$. In the past few decades, immigration to the UK has been on the rise (see Wheatley Price 2001 for a detailed history of UK immigration policy). In the period from 1975 to 1979 there was a net outflow of 21,000 people annually, but by 1994 to 1998 this trend had reversed and the UK was experiencing a net inflow of 73,000 migrants per year. This influx of immigrants increased particularly rapidly during the 1990s, and is responsible for about half of the population growth during that decade (Hatton and Tani 2003). In May 2004, ten Central and Eastern European countries joined the European Union (EU). The UK, along with Ireland and Sweden, were the only EU countries to initially grant full free movement of workers to these new accession nationals (Sriskandarajah 2004; Doyle et al. 2006). It is estimated that about 560,000 accession migrants joined the UK labor market between May 2004 and May 2006, which is roughly equivalent to 2 percent of total employment at that time. This is one of the largest inflows of migrants in British history (Salt and Miller 2006). Since 2004 over 1,000,000 migrants from accession countries have arrived in the UK; 
approximately half are thought to have subsequently returned home (Health Protection Agency 2008). Despite the large influx of immigrants, the effect on the labor market in terms of wages was relatively minor (Blanchflower and Lawton 2009). Perhaps one reason for the limited effect is that the numbers include both new migrants and newly legalized immigrants who were already in the country.

The profile of immigrants to the UK as reported in the British General Social Survey in the early 2000s suggests that 25.8 percent of recent immigrants migrated from continental Europe and Ireland (Kennedy et al. 2006). 18 percent originated from countries in Asia, 29.8 migrated to the UK from Africa and the Middle East, 7.1 percent from Canada, Australia and New Zealand, and 9.4 percent from the US and Caribbean nations.

This diverse group of immigrants joins a labor market that has been classified as one that is somewhat distinct from other European labor markets and shares some characteristics with the US labor market. These characteristics include relatively weak unions, wide and growing wage dispersion and high incidence of low-pay employment (Sapir 2006). Rovelli and Bruno (2008) classify the UK as one of the countries with the least generous labor market protections in the EU; a high poverty-low labor market protection country. During our period of study, the UK unemployment rate was relatively low, declining from 5.3 percent in 2000 to 4.8 percent in 2005.

\section{Literature review}

In this section we draw together insights from previous work in three largely unconnected literatures, the literature on the healthy immigrant hypothesis, the literature on the assimilation of immigrants to the labor market of the host country, and the large and growing literature that examines the consequences of obesity on labor market outcomes. We briefly review each of these in turn to place our work in context.

\subsection{The healthy immigrant effect}

The near consensus among researchers examining the status of immigrants upon arrival in developed countries points to a healthy immigrant effect (Choi 2011; Hao and Kim 2009; Park et al. 2009; Antecol and Bedard 2006; McDonald and Kennedy 2005; Tremblay et al. 2005; Kennedy et al. 2006). These studies suggest that upon arrival, immigrants exhibit better health than the native born in their new home country and are often healthier than those from their country of origin who do not migrate. In addition to reporting better initial health across a number of more traditional dimensions such as health behaviors, the prevalence of chronic conditions, and self-reported health (Jasso et al. 2004; Kennedy et al. 2006), many studies examining this phenomenon note specifically that immigrants have lower BMIs and are less likely to be classified as overweight or obese at the time of immigration (Kaplan et al. 2004; Park et al. 2009).

Some work has been done to try to disentangle the reasons for this healthy immigrant effect. A number of explanations have been offered (Antecol and Bedard 2006; Kennedy et al. 2006; Hao and Kim 2009). Individuals may migrate from countries that have substantially healthier nutrition and activity patterns. In addition, migrants may self select such that individuals investing in human capital through migration have chosen greater levels of health investment than non-migrators. It has also been 
suggested that the immigrant screening process may favor admission of only the healthiest immigrants. The pattern of healthy immigrants may also be caused, not solely by an inflow of healthy migrants, but by return migration of those in ill health (Hao and Kim 2009).

Current research also examines the degree to which assimilation erodes the initial health advantage of immigrants. The longer immigrants remain in their new destination the more they may adopt the diet and exercise behaviors and attitudes of their new neighbors (Hao and Kim 2009; Goel et al. 2004; Sorlie et al. 1993). For immigrants to Canada, the US and Australia, the adoption of native behaviors results in worse nutritional habits and an increase in obesity (Hao and Kim 2009; Antecol and Bedard 2006; McDonald and Kennedy 2005; Tremblay et al. 2005; Hauck and Hollingsworth 2009). Where these immigrants have strong cultural ties to their home country or live in areas with concentrated ethnic enclaves the process of unhealthy assimilation may be slowed (Hao and Kim 2009; McDonald and Kennedy 2005) ${ }^{4}$.

Many of the studies examining the healthy immigrant effect and convergence rely on cross-sectional data. Using repeated cross sections from the National Health Interview Survey, Antecol and Bedard (2006) carefully control for fixed period-of-arrival cohort effects and find results that are in keeping with prior work. In their study, immigrants recently arrived in the US are healthier and have lower BMIs and a lower incidence of obesity than do their native-born counterparts. Specifically, female immigrants to the US are nearly 10 percentage points more likely to be obese at the time of migration than their native-born counterparts. Within 10 years of their entry to the US, these immigrant women lose $90 \%$ of their healthy weight advantage (Antecol and Bedard 2006). Assimilation patterns have also been found to vary by education level. Increases in body weight are significantly more rapid for immigrants with less than a college degree (Kaushal 2009).

The results describing immigrant selection and assimilation with regard to BMI and obesity are consistent across studies that examine immigrants to the US, Canada and Australia. In contrast, studies that have examined obesity rates and assimilation for migrants to Europe find less consistent evidence that immigrants are healthier than the native population. In part this may be due to differences in the predominant countries of origin among immigrants to Western Europe. Kirchengast and Schobert (2006) find higher rates of overweight and obesity among adolescents recently migrating from Turkey and Yugoslavia to Austria. Studies in other countries report increased obesity and obesity-related health risks for migrants compared to natives in the Netherlands (Brussaard et al. 2001) and Germany (Bongard et al. 2002).

Our analysis focuses on immigrants to the UK and to date only one study has included an examination of obesity among these immigrants. In a comparative study of the general health of recent immigrants across four countries, Kennedy et al. (2006) find a healthy immigrant effect for the recently arrived foreign born in the UK in terms of obesity as well as chronic conditions and self-reported health.

\subsection{Immigrant labor market assimilation to the host country}

Much of the literature examining the wages of immigrants in their host country and their assimilation toward the level of wages paid to natives originated with studies of immigrants to the US (a classic paper is Chiswick 1978). Beginning with studies 
examining wage penalties for immigrants, researchers sought to identify the degree to which the penalty and rate of assimilation are determined by language ability (Trejo 1997; Chiswick and Miller 2002), and the timing and location of education (Friedberg 2000). In addition, Chiswick (1978) and Borjas $(1985,1995)$ emphasize that the selection process associated with international migration and the national origin mix of immigrants are crucial determinants of their labor market performance. In particular, those who choose to migrate are often those with better labor market prospects in the host country. Borjas $(1985,1995)$ finds evidence of substantial heterogeneity among immigrants and some evidence that individuals who invest in migration have greater earning potential. Finally, this literature has also examined changes in the quality of successive cohorts of immigrants (e.g. Borjas 1995).

A segment of this literature empirically examines these issues in the UK (e.g. Chiswick 1980; Bell 1997; Wheatley Price 2001). Much of this research focuses on role of race. Chiswick (1980) reports that white immigrants to the UK earned as much as their native counterparts but that non-white immigrants suffered a wage penalty as large as 25 percent which did not abate with increased time in the UK. Bell (1997) also finds that white immigrants fare well in the labor market while immigrants from the West Indies and India face an earnings disadvantage. As time since migration increased, the wage differential declined.

Shields and Wheatley Price (2002) find that language is positively related to the occupational success of immigrant groups in the UK, especially racial minorities. Using an instrumental variables approach they find that English language ability is the secondmost important factor, after education, in determining occupational status leading to higher wages.

Clark and Lindley (2005) use UK data to examine the employment and wage assimilation of immigrants to the UK with a focus on the acquisition of education. They report positive earnings assimilation for immigrants to the UK, and their findings suggest that employment assimilation is strongest for those immigrants who completed their education in the UK and then subsequently entered the job market. Differences in the returns to education for immigrants also exhibit striking differences by race. For most immigrants who acquired their education prior to entry to the UK, wage assimilation is much slower than for those who acquired it in the UK after migration. In addition, in what they term the 'scarring hypothesis' Clark and Lindley (2005) find that assimilation is particularly difficult if immigrants arrive in the UK during a period of high unemployment.

\subsection{Obesity and labor market outcomes}

As noted in the introduction, there is a large and growing literature aimed at determining the consequences of obesity in the labor market. Obesity may cause lower wages if employers discriminate against the obese or if obesity results in lower labor market productivity. However, the obese may simply possess less desirable personality traits that affect their productivity such as laziness or a lack of social skills, traits that the general public often associates with the obese (Sobal 2004). The obese may more heavily discount the future, making them more prone both to overeat and to invest less in wage-enhancing human capital (Zhang and Rashad 2008; Cawley 2004). Reverse 
causality is also possible such that those with lower wages become obese in part because they cannot afford healthy food and thus rely on calorie dense fast foods (Drewnowski 2009). Conversely the obese, believing their marriage market prospects are low, may invest more heavily in labor market oriented human capital, and thus have higher wages (Averett and Korenman 1996). Finally, cultural norms may play a role in whether or not there is a labor market penalty associated with obesity (Costa-Font and Gil 2004; Garcia and Quintana-Domeque 2006). Studies that only use OLS tend to find that the obese are penalized in the labor market in terms of both wages and employment (e.g. Pagán \& Dávila 1997; Garcia and Quintana-Domeque 2006; Klarenback et al. 2006), but a few find no effect (Lundborg et al. 2007; Johansson et al. 2009). These studies make use of data from the U.S. and several European countries.

The focus of much of the literature in this area has been on addressing the potential endogeneity between labor market outcomes and obesity and a number of strategies have been employed that include relying on temporal ordering using lagged measures of BMI, sibling- and individual-level fixed effects, and instrumental variables models (see Averett 2011 for a full discussion). Often, but by no means always, once the endogeneity of weight has been controlled for the negative effect of weight on earnings and employment is no longer statistically significant.

In the only study that examines the labor market penalty for obesity among immigrants, Cawley et al. (2009) use the New Immigrant Survey (NIS), the first nationally representative survey of legal immigrants in US history. This is the only US data set of which we are aware that contains data on labor market outcomes and obesity for immigrants. They analyze a sample of 2,321 women and 2,171 men comprised solely of immigrants who are from developing countries. The top five countries of origin in their sample are Mexico, India, El Salvador, the Philippines and China. They use the NIS to study four outcomes; wages, whether an individual is employed, whether the respondent suffers health related work limitations, and whether an employed respondent has a white-collar job.

The only significant association Cawley, Han and Norton find is that higher weight is associated with a lower probability of employment among immigrant women with a short duration of stay in the US. They report several limitations of their work that are common in this literature. They did not have longitudinal data, could not identify an instrument that could provide exogenous variation in weight, their sample size was limited, the data only have self reported weight and height, their data only included legal immigrants and some places of birth were defined by region.

There are several caveats regarding the above literature. First, in most studies height and weight are self-reported, which increases the likelihood of measurement error. There is evidence showing that this measurement error is not random, and the direction of the bias, and its extent, vary systematically with age and sex (Thomas and Frankenberg 2000). Second, BMI has been criticized as a measure of adiposity because it does not distinguish between fat and fat-free mass such as muscle and bone (Romero-Corral et al. 2006). Burkhauser and Cawley (2008) recommend using more accurate measures of fatness such as total body fat, percentage body fat, fat-free mass, and waist circumference, and they present a method for adjusting self-reported height and weight using $\mathrm{U}$ data. Wada and Tekin (2010) use these more accurate measures of body mass combined and find evidence that the obese suffer a wage penalty. Finally, there are also potential selection issues in both labor market status and wage equations. 
However, since standard selectivity correction techniques depend on specific functional form assumptions and the exogeneity of the variables of the selection equation, most studies examine the employment decision and the wage outcome in separate models.

\section{Methods, results and discussion}

In this section, we present our empirical model which extends that of Cawley et al. (2009). Using a similar methodology we examine the experiences of immigrants to the UK in the years 2004 and 2006, a time when the UK labor market was relatively strong and the UK experienced a large inflow of migrants.

\subsection{Description of the data}

The British Household Panel Survey (BHPS) is a nationally representative annual survey in the UK that began in 1991 with roughly 5,000 households that include over 9,000 adults. Several sub-samples have been added and removed from the survey over time: the European Community Household Panel (ECHP) from 1997 to 2001, the Scotland and Wales Extension from 1999 onward, and the Northern Ireland Household Panel Survey (NIHPS) from 2001 onward. In addition to these extensions, new members enter the survey when they join an original survey household by marriage, birth or cohabitation.

The BHPS allows us to identify immigrant status, obesity, and labor market outcomes. We use two questions to identify and categorize immigrants by country of origin and relocation duration: "Where were you born?" and "In what year did you first come to this country to live (even if you have spent time abroad)?" Both of these questions are only asked once; the first time an individual is interviewed if they report that they have not always lived at the same address and that their country of birth is not the UK. Given our limited sample, we form parsimonious groupings by country of origin as detailed in Table 1.

The BHPS collected information on height and weight only in two waves of the data, in 2004 and 2006. Weight and height are self reported and then used to calculate the BMI and indicator variables for the clinical weight classifications of overweight and obesity. In keeping with Cawley et al. (2009), we conduct our analyses on four different indicators of labor market outcomes. First, we examine whether immigrants face a wage penalty or premium for being obese or overweight by looking at labor income reported for the month prior to the interview. Monthly labor income is a derived variable (fimnl) that includes income from multiple sources including overtime and selfemployment. Next we look at whether or not individuals are employed (jbft), which includes both full-time (at least 30 hours per week) or part-time work. We create an indicator of work limitations from several variables in the BHPS that change during the sample period. These include direct measures of work limitations due to health or mental health conditions, and more specific questions about difficulty performing work ${ }^{5}$. Finally, we follow Balia and Jones (2008) in deriving social classifications from the Registrar General's social classification which is based on three-digit SIC codes (jbrgsc). We use this classification because it has the fewest missing observations, though the sample size for this regression is still slightly smaller than those of the other outcome measures. The social classifications are: professional and managerial, skilled 
Table 1 Immigrants to the UK - British Household Panel Survey, 2004, 2006 person-year observations

\begin{tabular}{|c|c|c|c|}
\hline Country of Origin & Women & Men & Total Immigrants \\
\hline Ireland & 119 & 70 & 189 \\
\hline Historical British Colonies United States, Canada, Australia, New Zealand & 46 & 43 & 89 \\
\hline $\begin{array}{l}\text { Other Europe Cyprus, Gibraltar, Malta, Belgium, Denmark, France, Italy, } \\
\text { Luxembourg, Netherlands, Germany, East Germany, Albania, Bulgaria, } \\
\text { Germany, Czechoslovakia, Hungary, Poland, Romania, Austria, Switzerland, } \\
\text { Greece, Portugal, Spain, Finland, Norway, Sweden, Yugoslavia, Turkey, USSR, } \\
\text { Other Europe }\end{array}$ & 149 & 81 & 230 \\
\hline India, Pakistan, Bangladesh, Sri Lanka & 58 & 43 & 101 \\
\hline $\begin{array}{l}\text { Far East Hong Kong, China, Japan, Malaysia, Singapore, Burma, Philippines, } \\
\text { Vietnam }\end{array}$ & 38 & 23 & 61 \\
\hline Middle East Libya, Egypt, Iran, Israel, other & 12 & 21 & 33 \\
\hline $\begin{array}{l}\text { Africa Kenya, Uganda, Tanzania, Malawi, Zambia, Zimbabwe, Botswana, } \\
\text { Gambia, Ghana, Nigeria, Sierra Leone, Seychelles, Mauritius, Algeria, } \\
\text { Morocco, Tunisia, South Africa, Other Africa }\end{array}$ & 46 & 56 & 102 \\
\hline $\begin{array}{l}\text { Caribbean \& Americas Barbados, Jamaica, Trinidad \& Tobago, } \\
\text { W. Indies, Other Caribbean, Belize, Guyana, Central America, South America }\end{array}$ & 20 & 12 & 32 \\
\hline Unique Person observations & 340 & 243 & 583 \\
\hline Total obs. (person years) & 488 & 349 & 837 \\
\hline
\end{tabular}

including those in the military, and semi and unskilled. A dichotomous indicator of a professional or managerial occupation is our dependent variable for the regressions on white collar work.

Our sample is restricted to respondents who report BMI data in at least one of the two waves resulting in a sample of 21,083 person-year observations from 14, 408 individuals. Of these individuals, 583 are immigrants. We observe 254 of these immigrants for both waves resulting in 837 person-year observations for immigrants with BMI information. Immigrants comprise 4.4 percent of the female sample and 3.4 percent of the male sample. This sample omits 5 observations for pregnant immigrants and 204 observations for pregnant natives because of the obvious association between pregnancy and reported weight. In addition, seven observations were deleted because of unreasonably low BMIs resulting from low reported weight. Complete summary statistics by gender and immigration status pooled for person-waves are presented in Table 2.

Notable in the unadjusted summary statistics is that immigrants, both men and women, have a higher average wage and higher proportions in managerial/professional jobs than UK natives. This reflects a positive selection of immigrants to the UK consistent with the findings of Dustmann et al. (2010) who analyzed data from the British Labour Force Survey from 1981 - 2005. The proportion of immigrants who are employed is similar to that of natives, although immigrant women are substantially more likely to report work limitations than native women. Also consistent with Dustmann, Glitz and Vogel, the majority of immigrants in our sample are from the West which includes other OECD countries. The average duration spent in the UK among immigrants in our sample is high (31.57 years and 33.99 years for women and men respectively). This long duration reflects the sample construction of the BHPS which only adds individuals to the sample if they join a household of an original sample member from 1991 or are part of one of the sub-samples which are not likely to include many 
Table 2 Summary Statistics

\begin{tabular}{|c|c|c|c|c|c|}
\hline \multirow[b]{2}{*}{ Variable } & \multicolumn{2}{|c|}{ Women } & \multicolumn{2}{|c|}{ Men } & \multirow[b]{2}{*}{ Total } \\
\hline & Immigrants & UK Natives & Immigrants & UK Natives & \\
\hline \multicolumn{6}{|l|}{ Weight indicators } \\
\hline BMI & 25.68 & 26.36 & 26.58 & 26.35 & 26.35 \\
\hline Underweight & $2.87 \%$ & $1.96 \%$ & $0.57 \%$ & $0.73 \%$ & $1.39 \%$ \\
\hline Recommended weight & $45.50 \%$ & $43.13 \%$ & $36.40 \%$ & $40.33 \%$ & $41.78 \%$ \\
\hline Overweight & $36.07 \%$ & $33.61 \%$ & $45.27 \%$ & $41.77 \%$ & $37.62 \%$ \\
\hline Obese & $15.57 \%$ & $21.30 \%$ & $17.77 \%$ & $17.17 \%$ & $19.21 \%$ \\
\hline \multicolumn{6}{|l|}{ Labor market indicators } \\
\hline Monthly Wages (£) & $\begin{array}{r}1,346.85 \\
(1,112.95)\end{array}$ & $\begin{array}{r}1,193.49 \\
(1,293.23)\end{array}$ & $\begin{array}{r}2,173.66 \\
(1,716.33)\end{array}$ & $\begin{array}{r}1,891.34 \\
(1,430.14)\end{array}$ & $\begin{array}{r}1,568.37 \\
(1,414.17)\end{array}$ \\
\hline Working (full or part time) & $52.87 \%$ & $54.13 \%$ & $67.91 \%$ & $67.82 \%$ & $60.64 \%$ \\
\hline Health limits work & $34.84 \%$ & $28.98 \%$ & $22.64 \%$ & $20.96 \%$ & $25.31 \%$ \\
\hline Managerial/Professional & $50.19 \%$ & $37.26 \%$ & $56.54 \%$ & $38.61 \%$ & $38.58 \%$ \\
\hline Skilled/Military & $33.20 \%$ & $42.78 \%$ & $30.38 \%$ & $43.82 \%$ & $42.90 \%$ \\
\hline Unskilled & $16.60 \%$ & $19.95 \%$ & $13.08 \%$ & $17.58 \%$ & $18.53 \%$ \\
\hline \multicolumn{6}{|l|}{ Demographic variables } \\
\hline Age & 50.11 & 47.73 & 49.61 & 45.93 & 46.99 \\
\hline Number of children & 0.55 & 0.51 & 0.55 & 0.47 & 0.49 \\
\hline Married & $53.69 \%$ & $50.79 \%$ & $67.34 \%$ & $55.31 \%$ & $53.21 \%$ \\
\hline College/professional degree & $51.23 \%$ & $36.94 \%$ & $53.58 \%$ & $42.94 \%$ & $40.31 \%$ \\
\hline High school/vocational degree & $21.11 \%$ & $37.17 \%$ & $22.06 \%$ & $36.18 \%$ & $36.10 \%$ \\
\hline No education/still in school & $25.62 \%$ & $24.17 \%$ & $22.92 \%$ & $18.38 \%$ & $21.51 \%$ \\
\hline Smoker & $17.83 \%$ & $25.14 \%$ & $31.23 \%$ & $25.33 \%$ & $25.16 \%$ \\
\hline Drinker & $0.20 \%$ & $0.42 \%$ & $1.15 \%$ & $0.76 \%$ & $0.58 \%$ \\
\hline Duration in the UK & 31.57 & $\mathrm{n} / \mathrm{a}$ & 33.99 & $\mathrm{n} / \mathrm{a}$ & $\mathrm{n} / \mathrm{a}$ \\
\hline Former British Colonies/Europe & $64.34 \%$ & $\mathrm{n} / \mathrm{a}$ & $55.59 \%$ & $\mathrm{n} / \mathrm{a}$ & $\mathrm{n} / \mathrm{a}$ \\
\hline East/Asia & $10.25 \%$ & $\mathrm{n} / \mathrm{a}$ & $12.61 \%$ & $\mathrm{n} / \mathrm{a}$ & $\mathrm{n} / \mathrm{a}$ \\
\hline From India/Pakistan & $11.88 \%$ & $\mathrm{n} / \mathrm{a}$ & $12.32 \%$ & $\mathrm{n} / \mathrm{a}$ & $n / a$ \\
\hline From Africa/S.America & $13.52 \%$ & $\mathrm{n} / \mathrm{a}$ & $19.48 \%$ & $\mathrm{n} / \mathrm{a}$ & $\mathrm{n} / \mathrm{a}$ \\
\hline White & $77.46 \%$ & $98.80 \%$ & $76.22 \%$ & $98.27 \%$ & $97.69 \%$ \\
\hline Black & $4.50 \%$ & $0.42 \%$ & $4.30 \%$ & $0.55 \%$ & $0.64 \%$ \\
\hline Asian & $17.62 \%$ & $0.49 \%$ & $18.05 \%$ & $0.74 \%$ & $1.30 \%$ \\
\hline Other race & $7.58 \%$ & $0.29 \%$ & $7.16 \%$ & $0.48 \%$ & $0.66 \%$ \\
\hline N (person-waves) & 488 & 10,526 & 349 & 9720 & 21,083 \\
\hline
\end{tabular}

Standard deviation for continuous variables in parentheses.

immigrants. That said, we do observe a range of duration from $1-85$ years with $10 \%$ of our immigrant observations residing in the UK for less than 8 years and $5 \%$ for less than 3 years.

Female immigrants have lower BMIs on average and a lower probability of being obese than native born women, and these differences are statistically significant at the one percent level. No other weight differences are statistically significant across immigrant status for either men or women.

The demographic variables reported in Table 2 suggest that immigrants to the UK are comparable in age and family structure compared with natives although immigrants 
are more likely to be married. We classify education as "college or professional" which includes teaching and nursing degrees, "vocational" which includes high school and apprenticeships, and "no education" which includes those still in school. Immigrants are overrepresented in both the highest and lowest education categories. Following Cawley et al. (2009), we include variables on current smoking status and whether or not the individual reports a problem with drinking in order to account for myopic time preferences ${ }^{6}$. Not surprisingly, immigrants are more likely to report being racial or ethnic minorities. We report these race categories in the summary statistics, but include region of origin rather than race in the regressions to better capture the effects of immigration ${ }^{7}$. Wheatley Price (2001) notes that country of origin variables may also capture variations in the quality of schooling, the transferability of skills between national labor markets, average English language ability, and systematic differences in unobserved ability, determined before migration by the prevailing characteristics of the origin country. Unfortunately, our data does not include information on English language proficiency.

\subsection{Healthy immigrant hypothesis}

To examine the presence of a healthy immigrant effect among immigrants to the UK, we estimate health differentials for immigrants controlling for individual characteristics as represented in the following equation:

$$
H_{i t}=\alpha+\beta X_{i t}+\phi I M M_{i}+\tau D U R_{i t}+\theta Y 2006_{t}+\epsilon_{i t}
$$

We look at two measures of health $\left(\mathrm{H}_{\mathrm{it}}\right)$ : $\mathrm{BMI}$ and an indicator of obesity $(\mathrm{BMI} \geq 30)$. $I M M$ is a dichotomous variable equal to one if the respondent is an immigrant, and $D U R$ is the number of years the respondent had been in the UK at the time of the survey (equal to zero if they are native born). Y2006 is a year fixed effect. The vector $X$ contains the demographic variables described above plus a quadratic age term.

The results in Table 3 generally support the healthy immigrant hypothesis. The coefficient on immigrant status is negative for both BMI and the likelihood of obesity for women and men, although the effects for men are smaller and do not reach conventional levels of significance. Controlling for individual characteristics such as age and education, female immigrants have a BMI that is slightly more than 2 points lower than that of comparable natives. The lower BMI levels among female immigrants translate into obesity rates that are 10.5 percentage points lower than that of native-born women. The positive significant coefficient on the duration variable shows evidence of an assimilation effect. However, the magnitude of this coefficient is relatively small, 0.037, suggesting that while the BMIs of immigrant women begin to approach those of natives, it would take nearly 60 years $(2.154 / .037)$ for immigrant women to gain the weight associated with the higher BMI of non-immigrant women. This slow rate of assimilation with respect to weight is also reflected in a very small and insignificant coefficient on duration in the obesity regression.

There are differences in weight associated with immigrant region of origin. The groupings are more parsimonious than those presented in Table 1. The omitted category is immigrants from former British colonies and Europe. The results for immigrants from India and Pakistan are the most strongly significant and in opposite directions for men and women. Immigrant women from India and Pakistan have a BMI that is 1.08 points lower $(-2.154+$ 
Table 3 Immigration and Weight: Full Sample of Immigrants and Natives

\begin{tabular}{|c|c|c|c|c|}
\hline \multirow[b]{2}{*}{ VARIABLES } & \multicolumn{2}{|c|}{ BMI } & \multicolumn{2}{|c|}{ Obesity (BMI $\geq 30$ ) } \\
\hline & Women & Men & Women & Men \\
\hline \multirow[t]{2}{*}{ Immigrant } & $-2.154^{* * *}$ & -0.458 & $-0.105^{* * *}$ & -0.075 \\
\hline & $(0.412)$ & $(0.474)$ & $(0.027)$ & $(0.048)$ \\
\hline \multirow[t]{2}{*}{ Duration in UK } & $0.037^{* * *}$ & 0.018 & 0.001 & 0.002 \\
\hline & $(0.010)$ & $(0.011)$ & $(0.001)$ & $(0.001)$ \\
\hline \multirow[t]{2}{*}{ East/Asia } & -0.056 & -0.638 & 0.038 & -0.007 \\
\hline & $(0.719)$ & $(0.523)$ & $(0.057)$ & $(0.061)$ \\
\hline \multirow[t]{2}{*}{ India/Pakistan } & $1.074^{*}$ & $-1.569^{* * *}$ & $0.113^{*}$ & -0.055 \\
\hline & $(0.611)$ & $(0.590)$ & $(0.062)$ & $(0.052)$ \\
\hline \multirow[t]{2}{*}{ Africa/S America } & -0.326 & 0.693 & -0.023 & $0.110^{*}$ \\
\hline & $(0.566)$ & $(0.635)$ & $(0.041)$ & $(0.060)$ \\
\hline \multirow[t]{2}{*}{ No education } & $1.427^{* * *}$ & $0.424^{* * *}$ & $0.094^{* * *}$ & $0.046^{* * *}$ \\
\hline & $(0.143)$ & $(0.127)$ & $(0.011)$ & $(0.011)$ \\
\hline \multirow[t]{2}{*}{ HSNocational } & $0.791^{* * *}$ & $0.265^{* * *}$ & $0.039^{* * *}$ & 0.010 \\
\hline & $(0.109)$ & $(0.094)$ & $(0.009)$ & $(0.008)$ \\
\hline \multirow[t]{2}{*}{ Age } & $0.320^{* * *}$ & $0.339^{* * *}$ & $0.015^{* * *}$ & $0.017^{* * *}$ \\
\hline & $(0.015)$ & $(0.013)$ & $(0.001)$ & $(0.001)$ \\
\hline \multirow[t]{2}{*}{ Age squared } & $-0.003^{* * *}$ & $-0.003^{* * *}$ & $-0.000^{* * *}$ & $-0.000^{* * *}$ \\
\hline & $(0.000)$ & $(0.000)$ & $(0.000)$ & $(0.000)$ \\
\hline \multirow[t]{2}{*}{ Smoker } & $-0.962^{* * *}$ & $-0.898^{* * *}$ & $-0.042^{* * *}$ & $-0.052^{* * *}$ \\
\hline & $(0.118)$ & $(0.099)$ & $(0.009)$ & $(0.008)$ \\
\hline \multirow[t]{2}{*}{ Drinker } & $-1.558^{*}$ & $-1.692^{* * *}$ & -0.014 & -0.051 \\
\hline & $(0.872)$ & $(0.531)$ & $(0.060)$ & $(0.037)$ \\
\hline \multirow[t]{2}{*}{ Married } & 0.093 & $0.180^{*}$ & 0.005 & 0.001 \\
\hline & $(0.114)$ & $(0.106)$ & $(0.009)$ & $(0.010)$ \\
\hline \multirow[t]{2}{*}{ Number of children } & -0.035 & $0.123^{* *}$ & -0.004 & 0.000 \\
\hline & $(0.057)$ & $(0.056)$ & $(0.004)$ & $(0.005)$ \\
\hline \multirow[t]{2}{*}{ Year 2006} & $2.054^{* * *}$ & $0.537^{* * *}$ & $0.110^{* * *}$ & $0.026^{* * *}$ \\
\hline & $(0.101)$ & $(0.084)$ & $(0.008)$ & $(0.008)$ \\
\hline \multirow[t]{2}{*}{ Constant } & $17.658^{* * *}$ & $18.318^{* * *}$ & $-0.204^{* * *}$ & $-0.199 * * *$ \\
\hline & $(0.318)$ & $(0.281)$ & $(0.023)$ & $(0.022)$ \\
\hline Observations & 11,013 & 10,069 & 11,013 & 10,069 \\
\hline R-squared & 0.110 & 0.102 & 0.047 & 0.030 \\
\hline
\end{tabular}

Robust standard errors in parentheses. ${ }^{* *} \mathrm{p}<0.01,{ }^{* *} \mathrm{p}<0.05,{ }^{*} \mathrm{p}<0.1$.

Obesity is a logit model with marginal effects reported.

1.074) than native women in the $\mathrm{UK}^{8}$. In contrast, men from India and Pakistan are have a BMI that is 2.027 BMI points lower $(-.458+-1.569)$ than comparable natives. Other significant immigrant effects by region include results for Africa and South America ${ }^{9}$. We see evidence contrary to the healthy immigrant hypothesis in that male immigrants from these regions experience higher $\mathrm{BMI}$ and a significant 3.5 percentage point higher $(-0.075+.11)$ probability of obesity. Weight measures for immigrants from East/Asia are not significantly difference from the omitted category of immigrants from Europe and the former colonies.

The associations between BMI and obesity and other covariates are in line with previous studies. For example, BMI and obesity increase with age at a diminishing rate for 
both women and men. Marriage and children are associated with higher BMI for men, but not women. Though existing work consistently shows that BMI tends to rise after marriage, OLS models that combine the selection of thinner individuals into marriage and the impact of marriage on weight demonstrate much weaker correlations (Averett et al. 2008). Lower levels of education (college professional is the omitted category) are associated with higher weight while smoking and drinking are strongly associated with lower weight for both men and women.

\subsection{Labor market outcomes: immigrants only}

We begin our analysis of immigration, obesity and labor market outcomes by estimating models similar to those reported by Cawley et al. (2009) on the immigrant-only sample. Our results, like those of Cawley et al. (2009), can only be viewed as associations since we are unable to instrument for BMI and small sample and cell sizes make individual fixed-effects models infeasible. Our empirical model takes the following form:

$$
L_{i t}=\alpha+\beta X_{i t}+\gamma O W_{i t}+\eta O B_{i t}+\tau D U R_{i t}+\theta Y 2006_{t}+\epsilon_{i t}
$$

$L$ represents one of four labor market outcomes previously described. We classify individuals as overweight $(O W)$ and obese $(O B)$ with recommended weight and underweight combined as the omitted category. We estimate log wage equations using OLS and logit models for employment, work limitations and white collar work. Estimates of equation (2) are presented in Table 4 for each of our four labor market outcomes. Marginal effects are reported for logit models of employment, work limitations and white collar work.

Despite our smaller sample size, we find more significance in the effects of overweight and obesity on labor market outcomes among an immigrant-only sample in the UK than Cawley et al. (2009) found among immigrants to the US. However, beyond the different institutional settings between the UK and the US, our sample includes a large proportion of immigrants from developed countries including the US, Canada and Australia while their sample consists of immigrants from developing countries.

Overall, the results demonstrate a negative association between overweight and obesity and labor market outcomes for immigrants to the UK. The wage penalties range from -12.7 percent for overweight women to -17.5 percent for obese men, though the large standard errors preclude any of these estimates reaching conventional levels of significance. These models also control for length of time in the U.K. Duration has a small positive effect only on the earnings of women indicating that wages for women gradually increase with duration but at a rate of 1 percent per year.

We find a sizeable and strongly significant association between overweight and obesity and the report of health-related work limitations for immigrant women. Female immigrants who are overweight or obese are 12.3 percentage point and 18.4 percentage points more likely to report such limitations than healthy weight immigrants. For men, we find a significant difference of 11.6 percentage points for obese men only.

Finally, we find large negative associations between overweight and obesity and being in a white collar job. The associations are very similar for men and women at approximately 11 percentage points for those overweight and 17 percentage points for those obese. We do not find any significant associations between weight and being employed. 
Table 4 Marginal Effects of Weight on Labor Market Outcomes. Immigrants Only Sample.

\begin{tabular}{|c|c|c|c|c|c|c|c|c|}
\hline \multirow[b]{2}{*}{ VARIABLES } & \multicolumn{2}{|c|}{ Ln Wages } & \multicolumn{2}{|c|}{ Working } & \multicolumn{2}{|c|}{ Work Limitations } & \multicolumn{2}{|c|}{ Professional/Managerial } \\
\hline & Women & Men & Women & Men & Women & Men & Women & Men \\
\hline \multirow[t]{2}{*}{ Overweight } & -0.127 & -0.164 & 0.042 & -0.021 & $0.123^{* * *}$ & -0.020 & $-0.110^{*}$ & $-0.118^{*}$ \\
\hline & $(0.112)$ & $(0.117)$ & $(0.044)$ & $(0.041)$ & $(0.045)$ & $(0.048)$ & $(0.061)$ & $(0.061)$ \\
\hline \multirow[t]{2}{*}{ Obese } & -0.141 & -0.175 & 0.049 & -0.001 & $0.184^{* * *}$ & $0.116^{* *}$ & $-0.174^{*}$ & $-0.161^{*}$ \\
\hline & $(0.137)$ & $(0.116)$ & $(0.051)$ & $(0.055)$ & $(0.057)$ & $(0.057)$ & $(0.089)$ & $(0.083)$ \\
\hline \multirow[t]{2}{*}{ Duration in UK } & $0.010^{* *}$ & -0.005 & 0.000 & -0.001 & 0.000 & -0.001 & 0.003 & -0.003 \\
\hline & $(0.004)$ & $(0.004)$ & $(0.001)$ & $(0.001)$ & $(0.001)$ & $(0.001)$ & $(0.002)$ & $(0.002)$ \\
\hline \multirow[t]{2}{*}{ East/Asia } & $0.267^{* *}$ & -0.118 & 0.006 & 0.014 & 0.073 & -0.044 & -0.046 & -0.007 \\
\hline & $(0.126)$ & $(0.184)$ & $(0.064)$ & $(0.070)$ & $(0.064)$ & $(0.072)$ & $(0.075)$ & $(0.083)$ \\
\hline \multirow[t]{2}{*}{ India/Pakistan } & -0.329 & 0.023 & $-0.125^{* *}$ & $-0.142^{* * *}$ & $0.189^{* * *}$ & $0.100^{*}$ & $-0.262^{* * *}$ & 0.162 \\
\hline & $(0.218)$ & $(0.178)$ & $(0.053)$ & $(0.053)$ & $(0.061)$ & $(0.054)$ & $(0.093)$ & $(0.110)$ \\
\hline \multirow[t]{2}{*}{ Africa/S. America } & -0.010 & 0.091 & 0.040 & $-0.097^{* *}$ & 0.094 & $-0.138^{*}$ & 0.038 & -0.024 \\
\hline & $(0.150)$ & (0.138) & $(0.051)$ & $(0.047)$ & $(0.064)$ & $(0.078)$ & $(0.073)$ & $(0.073)$ \\
\hline \multirow[t]{2}{*}{ No education } & $-0.449^{* * *}$ & $-0.559^{* * *}$ & $-0.218^{* * *}$ & $-0.225^{* * *}$ & 0.060 & $0.106^{* *}$ & $-0.488^{* * *}$ & $-0.486^{* * *}$ \\
\hline & $(0.155)$ & $(0.181)$ & $(0.041)$ & $(0.045)$ & $(0.047)$ & $(0.051)$ & (0.119) & (0.104) \\
\hline \multirow[t]{2}{*}{ HS/vocational } & $-0.445^{* * *}$ & $-0.353^{* * *}$ & $-0.103^{* *}$ & -0.073 & -0.019 & 0.072 & $-0.268^{* * *}$ & $-0.302^{* * *}$ \\
\hline & (0.118) & $(0.118)$ & $(0.042)$ & $(0.046)$ & $(0.055)$ & $(0.054)$ & $(0.060)$ & $(0.055)$ \\
\hline \multirow[t]{2}{*}{ Smoker } & -0.089 & -0.177 & -0.012 & -0.051 & $0.145^{* * *}$ & 0.046 & $-0.191^{* *}$ & $-0.200^{* * *}$ \\
\hline & $(0.150)$ & $(0.111)$ & $(0.046)$ & $(0.035)$ & $(0.052)$ & $(0.045)$ & $(0.077)$ & $(0.060)$ \\
\hline \multirow[t]{2}{*}{ Drinker } & $-0.919^{* * *}$ & 0.005 & & 0.099 & & $0.307^{*}$ & & 0.452 \\
\hline & $(0.180)$ & $(0.161)$ & & $(0.092)$ & & (0.159) & & $(0.318)$ \\
\hline \multirow[t]{2}{*}{ Age } & $0.103^{* *}$ & $0.107^{* * *}$ & $0.037^{* * *}$ & $0.035^{* * *}$ & 0.004 & $-0.015^{* *}$ & $0.025^{*}$ & $0.043^{* * *}$ \\
\hline & $(0.040)$ & $(0.020)$ & $(0.010)$ & (0.008) & $(0.007)$ & $(0.007)$ & $(0.014)$ & $(0.012)$ \\
\hline \multirow[t]{2}{*}{ Age squared } & $-0.001^{* * *}$ & $-0.001^{* * *}$ & $-0.001^{* * *}$ & $-0.000^{* * *}$ & 0.000 & $0.000^{* * *}$ & -0.000 & $-0.000^{* * *}$ \\
\hline & $(0.000)$ & $(0.000)$ & $(0.000)$ & $(0.000)$ & $(0.000)$ & $(0.000)$ & $(0.000)$ & $(0.000)$ \\
\hline \multirow[t]{2}{*}{ Married } & $0.225^{*}$ & 0.001 & 0.017 & 0.076 & -0.019 & 0.067 & 0.098 & $-0.128^{*}$ \\
\hline & (0.123) & $(0.136)$ & $(0.041)$ & $(0.055)$ & $(0.044)$ & $(0.054)$ & $(0.060)$ & $(0.077)$ \\
\hline \multirow[t]{2}{*}{ Number of children } & $-0.428^{* * *}$ & -0.004 & $-0.082^{* * *}$ & -0.015 & $-0.048^{*}$ & -0.012 & $-0.069^{* *}$ & 0.004 \\
\hline & $(0.066)$ & $(0.072)$ & (0.018) & $(0.023)$ & $(0.025)$ & $(0.027)$ & $(0.033)$ & $(0.034)$ \\
\hline \multirow[t]{2}{*}{ Year 2006} & 0.061 & 0.157 & 0.050 & -0.025 & $-0.072^{*}$ & -0.035 & $0.130^{* *}$ & 0.046 \\
\hline & $(0.102)$ & $(0.106)$ & (0.037) & $(0.035)$ & $(0.041)$ & $(0.042)$ & (0.058) & (0.058) \\
\hline \multirow[t]{2}{*}{ Constant } & $5.425^{* * *}$ & $5.441^{* * *}$ & & & & & & \\
\hline & $(0.806)$ & $(0.423)$ & & & & & & \\
\hline Observations & 259 & 237 & 487 & 349 & 487 & 349 & 258 & 237 \\
\hline R-squared & 0.279 & 0.172 & & & & & & \\
\hline
\end{tabular}

Robust standard errors in parentheses. Work limits, and professional/managerial are logit models with marginal effects reported.

${ }^{* * *} p<0.01,{ }^{* *} p<0.05,{ }^{*} p<0.1$. Drinker was dropped due to collinearity in small samples for women in the logit models.

\subsection{Labor market outcomes: immigrants and natives}

Since our sample includes both immigrants and natives, we can extend Cawley et al. (2009) to directly compare the immigrant and native populations with respect to the effect of weight on labor market outcomes. We do this by estimating the following equation which augments equation (2) by including an indicator of immigration status 
$(I M M)$ and interaction effects between immigration and weight classifications and a control for duration in the UK for immigrants (this variable is 0 for natives):

$$
\begin{aligned}
L_{i t} & =\alpha+\beta X_{i t}+\Gamma I M M_{i}+\gamma O W_{i t}+\eta O B_{i t}+\phi\left(I M M_{i} * O W_{i t}\right) \\
& +\lambda\left(I M M_{i} * O B_{i t}\right)+\tau D U R_{i t}+\theta Y 2006_{t}+\epsilon_{i t}
\end{aligned}
$$

The key coefficients of interest are $\phi$ and $\lambda$, the coefficients on the interactions of immigrant and weight status. Table 5 reports the results from this analysis.

The strongest finding of these regressions is a wage penalty for overweight and obese immigrant men of 25 percent and 27 percent respectively. This wage penalty for immigrant men is in contrast to the wage premium of 6-7 percent that we find for overweight and obese native born men. The finding of a wage premium for overweight and obese native men is consistent with findings from other studies that have used OLS (see Brunello and d'Hombres 2007; Morris 2006, 2007). We find negative coefficients of 15.8 and 19 percent for overweight and obese immigrant women, but while sizeable they are not significant at conventional levels.

Turning to the probability of employment, we find that obese immigrant women experience a nearly 9 percentage point greater probability of working. This finding is marginally significant. This stands in contrast with a strongly significant finding that obese native women are associated with a nearly 5 percentage point lower probability of working. However, a joint F-test on the coefficients of obese and the interaction between obesity and immigrant does not reach conventional levels of significance $(\mathrm{p}=.405)$. We find a positive association between being overweight and working for native born women and men. One potential explanation for this finding is, as noted earlier, BMI may not be the best measure of adiposity since someone who is very muscular may be classified as overweight on the basis of BMI.

Work limitations are more prevalent among the obese for both native men and women. Notably, overweight immigrant women are 11.9 percentage points more likely to have work limitations all else equal, and this finding is strongly significant. Associations for overweight immigrant men and for obese immigrants of both genders are smaller and not statistically significant.

The last labor market outcome in Table 5 is whether or not the respondent is in a professional or managerial job, which in keeping with Cawley et al. (2009), we refer to as "white collar." We find significant associations between overweight and obesity and white collar work for men, but not for women. Native men are less likely to be in professional or managerial jobs if they are overweight (2.3 percentage points) or obese (4.8 percentage points). As we saw in the means, immigrants overall are more likely to be in white collar occupations. Overweight and obese male immigrants, however, are less likely to be in these jobs $(-10.5$ and -12.1 percentage points respectively) although the association is statistically significant only for overweight immigrant men.

All of the models include indicators for the immigrant's region of origin with the omitted category consisting of other countries in Europe, the US, Canada and Australia. As noted, a majority of the immigrants in our sample come from this omitted category, and our broad groupings were dictated by our limited sample size. Nonetheless, we find consistent negative associations for female immigrants from India and Pakistan across all of the labor market outcomes. The wage penalty for women from this region is 
Table 5 Marginal Effects of Weight on Labor Market Outcomes: Full Sample of Immigrants and Natives

\begin{tabular}{|c|c|c|c|c|c|c|c|c|}
\hline \multirow[b]{2}{*}{ VARIABLES } & \multicolumn{2}{|c|}{ Ln Wages } & \multicolumn{2}{|c|}{ Working } & \multicolumn{2}{|c|}{ Work Limitations } & \multicolumn{2}{|c|}{ Professional/Managerial } \\
\hline & Women & Men & Women & Men & Women & Men & Women & Men \\
\hline \multirow[t]{2}{*}{ Overweight } & $0.044^{*}$ & $0.063^{* * *}$ & $0.021^{* *}$ & $0.023^{* * *}$ & 0.012 & 0.009 & 0.006 & $-0.023^{*}$ \\
\hline & $(0.023)$ & $(0.020)$ & $(0.009)$ & $(0.008)$ & $(0.010)$ & $(0.009)$ & $(0.014)$ & $(0.013)$ \\
\hline \multirow[t]{2}{*}{ Obese } & 0.020 & $0.070^{* * *}$ & $-0.047^{* * *}$ & -0.014 & $0.109^{* * *}$ & $0.064^{* * *}$ & -0.013 & $-0.048^{* * *}$ \\
\hline & $(0.027)$ & $(0.026)$ & $(0.010)$ & $(0.010)$ & $(0.011)$ & $(0.011)$ & $(0.016)$ & $(0.016)$ \\
\hline \multirow[t]{2}{*}{ Immigrant } & -0.034 & 0.163 & -0.028 & 0.034 & -0.051 & 0.048 & 0.001 & $0.187^{* *}$ \\
\hline & $(0.111)$ & $(0.127)$ & $(0.041)$ & $(0.061)$ & $(0.049)$ & $(0.052)$ & $(0.063)$ & $(0.074)$ \\
\hline \multirow[t]{2}{*}{ Immigrant*Overweight } & -0.158 & $-0.249 * *$ & 0.016 & -0.034 & $0.119^{* * *}$ & -0.028 & -0.080 & $-0.105^{*}$ \\
\hline & $(0.112)$ & $(0.117)$ & $(0.041)$ & $(0.053)$ & $(0.043)$ & $(0.047)$ & $(0.063)$ & $(0.064)$ \\
\hline \multirow[t]{2}{*}{ Immigrant *Obese } & -0.190 & $-0.268^{* *}$ & $0.088^{*}$ & 0.004 & 0.077 & 0.035 & -0.121 & -0.121 \\
\hline & $(0.145)$ & $(0.116)$ & $(0.051)$ & $(0.066)$ & $(0.054)$ & $(0.060)$ & $(0.090)$ & $(0.083)$ \\
\hline \multirow[t]{2}{*}{ Duration in UK } & 0.005 & 0.001 & -0.000 & 0.001 & 0.000 & -0.001 & $0.005^{* *}$ & -0.000 \\
\hline & $(0.003)$ & $(0.004)$ & $(0.001)$ & $(0.001)$ & $(0.001)$ & $(0.001)$ & $(0.002)$ & $(0.002)$ \\
\hline \multirow[t]{2}{*}{ East/Asia } & 0.209 & -0.181 & -0.004 & -0.002 & 0.068 & -0.063 & -0.054 & -0.008 \\
\hline & $(0.137)$ & $(0.187)$ & $(0.061)$ & $(0.077)$ & $(0.060)$ & $(0.070)$ & $(0.083)$ & $(0.078)$ \\
\hline \multirow[t]{2}{*}{ India/Pakistan } & $-0.346^{*}$ & -0.007 & $-0.132^{* * *}$ & $-0.169^{* * *}$ & $0.147^{* * *}$ & 0.080 & $-0.248^{* *}$ & 0.137 \\
\hline & $(0.181)$ & $(0.179)$ & $(0.051)$ & $(0.063)$ & $(0.056)$ & $(0.056)$ & $(0.104)$ & $(0.112)$ \\
\hline \multirow[t]{2}{*}{ Africa/S. America } & -0.094 & 0.085 & 0.035 & $-0.103^{*}$ & 0.087 & $-0.160^{* *}$ & 0.028 & 0.007 \\
\hline & $(0.153)$ & $(0.131)$ & $(0.052)$ & $(0.053)$ & $(0.057)$ & $(0.070)$ & $(0.073)$ & $(0.071)$ \\
\hline \multirow[t]{2}{*}{ No education } & $-0.676^{* * *}$ & $-0.387^{* * *}$ & ${ }^{*}-0.203^{* * *}$ & $-0.125^{* * *}$ & $0.066^{* * *}$ & $0.085^{* * *}$ & $-0.515^{* * *}$ & $-0.329^{* * *}$ \\
\hline & $(0.035)$ & $(0.034)$ & $(0.010)$ & $(0.010)$ & $(0.011)$ & $(0.010)$ & $(0.029)$ & $(0.020)$ \\
\hline \multirow[t]{2}{*}{ HS/vocational } & $-0.375^{* * *}$ & $-0.242^{* * *}$ & $*-0.093^{* * *}$ & $-0.044^{* * *}$ & 0.008 & $0.028^{* * *}$ & $-0.283^{* * *}$ & $-0.228^{* * *}$ \\
\hline & $(0.021)$ & $(0.018)$ & $(0.008)$ & $(0.008)$ & $(0.010)$ & $(0.009)$ & $(0.010)$ & $(0.011)$ \\
\hline \multirow[t]{2}{*}{ Smoker } & $-0.047^{* *}$ & -0.023 & $-0.042^{* * *}$ & $-0.052^{* * *}$ & $0.082^{* * *}$ & $0.059^{* * *}$ & $-0.045^{* * *}$ & $-0.106^{* * *}$ \\
\hline & $(0.022)$ & $(0.020)$ & $(0.008)$ & $(0.008)$ & $(0.010)$ & $(0.009)$ & $(0.014)$ & $(0.013)$ \\
\hline \multirow[t]{2}{*}{ Drinker } & 0.334 & -0.093 & $-0.255^{* * *}$ & $-0.261^{* * *}$ & $0.359^{* * *}$ & $0.237^{* * *}$ & $0.167^{*}$ & 0.037 \\
\hline & $(0.337)$ & $(0.197)$ & $(0.063)$ & $(0.034)$ & $(0.062)$ & $(0.036)$ & $(0.095)$ & $(0.112)$ \\
\hline \multirow[t]{2}{*}{ Age } & $0.158^{* * *}$ & $0.138^{* * *}$ & $0.049^{* * *}$ & $0.038^{* * *}$ & 0.002 & $0.003^{* *}$ & $0.034^{* * *}$ & $0.032^{* * *}$ \\
\hline & $(0.006)$ & $(0.005)$ & $(0.001)$ & $(0.001)$ & $(0.001)$ & $(0.001)$ & $(0.003)$ & $(0.003)$ \\
\hline \multirow[t]{2}{*}{ Age squared } & $-0.002^{* * *}$ & $-0.002^{* * *}$ & $*-0.001^{* * *}$ & $-0.001^{* * *}$ & $0.000^{* * *}$ & $0.000^{* *}$ & $-0.000^{* * *}$ & $-0.000^{* * *}$ \\
\hline & $(0.000)$ & $(0.000)$ & $(0.000)$ & $(0.000)$ & $(0.000)$ & $(0.000)$ & $(0.000)$ & $(0.000)$ \\
\hline \multirow[t]{2}{*}{ Married } & $-0.105^{* * *}$ & $0.076^{* * *}$ & $0.036^{* * *}$ & $0.062^{* * *}$ & $-0.039^{* * *}$ & $-0.030^{* * *}$ & $-0.026^{* *}$ & 0.011 \\
\hline & $(0.022)$ & $(0.021)$ & $(0.009)$ & $(0.009)$ & $(0.009)$ & $(0.009)$ & $(0.013)$ & $(0.014)$ \\
\hline \multirow[t]{2}{*}{ Number of children } & $-0.222^{* * *}$ & 0.009 & $-0.095^{* * *}$ & -0.001 & 0.008 & -0.003 & $-0.019^{* * *}$ & -0.000 \\
\hline & $(0.013)$ & $(0.010)$ & $(0.004)$ & $(0.005)$ & $(0.005)$ & $(0.005)$ & $(0.007)$ & $(0.007)$ \\
\hline \multirow[t]{2}{*}{ Year 2006} & $0.067^{* * *}$ & $0.075^{* * *}$ & -0.005 & 0.005 & $-0.088^{* * *}$ & $-0.033^{* * *}$ & 0.008 & 0.009 \\
\hline & $(0.021)$ & $(0.018)$ & $(0.008)$ & $(0.007)$ & $(0.009)$ & (0.008) & $(0.012)$ & $(0.011)$ \\
\hline Observations & 6,012 & 6,803 & 11,013 & 10,069 & 11,013 & 10,069 & 5,959 & 6,842 \\
\hline R-squared & 0.246 & 0.248 & & & & & & \\
\hline
\end{tabular}

Robust standard errors in parentheses. ${ }^{* * *} p<0.01,{ }^{* *} p<0.05,{ }^{*} p<0.1$. Lnwage models include a constant term which is not shown. Work limits, and professional/managerial are logit models with marginal effects reported. 
estimated to be over 34 percent, second in magnitude only to the nearly 70 percent penalty associated with having no education ${ }^{10}$. Women from India/Pakistan are 13.2 percentage points less likely to be working, 14.7 percentage points more likely to report work limitations, and nearly 25 percentage points less likely to be in white collar jobs. We do not find a significant wage penalty for men from India/Pakistan but we do find a strong negative association with employment and a positive but not statistically significant association with white collar work ${ }^{11}$.

Briefly looking at the other covariates in the model, we find associations that are consistent with economic theory. Higher educational attainment is strongly associated with better labor market outcomes. Age is positively associated with wages, employment and white collar work, but also positively associated with the probability of reporting work limitations. We find a marriage wage penalty for women and premium for men though marriage is positively associated with working and negatively associated with work limitations for both. Children are negatively associated with wages, working and white collar work for women, but not for men. Finally, we find a strong negative association between smoking and labor market outcomes and to a lesser extent between drinking and labor market outcomes.

\section{Conclusion}

In this paper we have offered new evidence on the dual effects of immigration and obesity on labor market outcomes for immigrants to the UK. We find several significant associations. First, we find evidence supporting the healthy immigrant hypothesis particularly for women in that the BMI of immigrants is strongly and significantly lower than that of natives, and immigrants have a lower probability of obesity than natives. In addition, we find evidence consistent with other literature on immigration to the UK (e.g. Dustmann et al. 2010) of a wage premium, although imprecisely estimated, and an increased likelihood of working in a white collar job for male immigrants. Despite a wage premium for overweight and obese men in general, we find a wage penalty for overweight and obese immigrant men. Our findings for female immigrants are generally consistent with those for male immigrants in sign, and are often of sizable magnitude but are not significant at conventional levels. This may be due to greater selection effects associated with women's decisions about whether or not to enter the labor market in the first place. It is important to note that our findings are associations and cannot confirm causation due to data limitations that preclude effectively addressing the endogeneity between weight and labor market outcomes. Endogeneity associated with both reverse causality and unobservable characteristics correlated with both weight and labor market outcomes is a challenge throughout the literature in this area. It is particularly challenging here because of the limited data sets that combine height, weight, immigration status and labor market outcomes with adequate sample sizes of immigrants. Neither our data nor that used by Cawley et al. (2009) include suitable instruments. In addition, our data includes only two adjacent waves precluding any reasonable fixed effects analysis. Therefore, a critical need for future research is better data over a longer time period.

Nonetheless, our findings suggest that the obesity epidemic has not spared immigrants to the UK, but that obesity has a more severe impact on labor market outcomes for male immigrants than natives. Since the UK has a National Health Service, targeted 
outreach to overweight and obese immigrants may have a dual effect of both lowering health care costs and increasing labor market outcomes among this vulnerable population.

\section{Endnotes}

${ }^{1}$ Earlier research by the authors provides an overview of these issues (see Averett et al. forthcoming).

${ }^{2} \mathrm{BMI}$ is measured as weight in kilometers divided by height squared where height is measured in meters, Clinical indicators for overweight and obesity in terms of BMI are $(25 \leq \mathrm{BMI}<30)$ for overweight $(\mathrm{BMI} \geq 30)$ for obese.

${ }^{3}$ In 2009, the latest year for which data is available, the countries receiving the largest inflows of permanent foreign population immigrants according to OECD were, in order: US, Germany, UK, Spain, Canada and Australia.

${ }^{4}$ While immigrants locating in dense ethnic enclaves have been found to gain an advantage in terms of health, such location may hinder their acquisition of the language in their host country and slow labor market assimilation (Chiswick 2005).

${ }^{5}$ Our indicator of work limitations is an aggregation of positive answers to questions about "health prohibits some type of work" (hlendw), "health limits type or amount of work" (hlltw) which are available in 2006 and more detailed questions about physical health limiting the amount of time spent on work, accomplishing less, limiting kinds of work and difficulty performing work (hlsf4a,b,c and d) as well as questions regarding mental health limiting work (hlsf5a,b and c) which are only available in 2004.

${ }^{6}$ The drinking variable available in the BHPS is limited to self-reported problem drinking which likely explains why drinking rates are low in our sample.

${ }^{7}$ We were unable to include both race and region because of collinearity that is exacerbated in our limited sample. We also ran our models replacing region with race. The results are similar and are available upon request.

8 This finding is based on 72 individuals representing 101 person-year observations for female immigrants from this region.

${ }^{9}$ We observe 94 individuals for 135 person-year observations from this region.

10 This finding is based on observing 58 person-year observations for 41 female immigrants from this region.

${ }^{11}$ This finding is based on 31 individuals contributing 43 person-year observations.

Competing interests

The IZA Journal of Migration is committed to the IZA Guiding Principles of Research Integrity. The authors declare that they have observed these principles.

\section{Acknowledgement}

We would like to acknowledge the editor, an anonymous referee, and Amelie F. Constant for helpful comments. The data used in this research were made available through the ESRC Data Archive. The data were originally collected by the ESRC Research Center on Micro-social Change at the University of Essex. Neither the original collectors of the data nor the Archive bear any responsibility for the analysis nor the interpretations presented here. The authors are responsible for any errors.

Responsible Editor: Amelie F. Constant

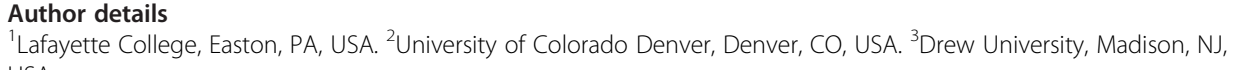




\section{References}

Antecol H, Bedard K (2006) Unhealthy assimilation: why do immigrants converge to American health status levels? Demogr 3(2):337-360

Averett S, Argys L, Kohn J (forthcoming) "Immigrants, Wages and Obesity: The Weight of the Evidence" in the International Handbook on the Economics of Migration.

Averett S (2011) Labor market consequences: employment, wages, disability, and absenteeism. In: Cawley J (ed) The Oxford Handbook of the Social Science of Obesity. Oxford University Press, New York, pp 531-552

Averett S, Sikora A, Argys L (2008) For better or worse: relationship status and body mass index. Econ Hum Biol 6(3):330-349

Averett S, Korenman S (1996) The economic reality of the beauty myth. J Hum Resour 31:304-330

Balia S, Jones A (2008) Mortality, lifestyle and socio-economic status. J Health Econ 27(1):1-26

Bell B (1997) The Performance of Immigrants in the United Kingdom: Evidence from the GHS. The Econ J 107(441):333-344

Blanchflower D, Lawton H (2009) The Impact of the recent expansion of the EU on the UK labor market. EU Labor Markets After Post-Enlargement Migration. In: Kahanec M, Zimmermann K (eds). Springer, Berlin, pp 181-214

Bongard S, Pogge S, Arslaner H, Rohrmann S, Hodapp V (2002) Acculturation and cardiovascular reactivity of secondgeneration Turkish migrants in Germany. J of Psychometric Research 53:795-803

Borjas G (1985) Assimilation, changes in cohort quality, and the earnings of immigrants. J of Labor Econ 3:463-489

Borjas $G$ (1995) Assimilation and changes in cohort quality revisited: what happened to immigrant earnings in the 1980s? J of Labor Econ 13(2):201-245

Brunello G, D'Hombres B (2007) Does body weight affect wages?: Evidence from Europe. Econ Hum Biol 5:1-19

Brussaard JH, van Erp-Baart MA, Brants K, Hulshof M, Lowik M (2001) Nutrition and health among migrants in the Netherlands. Public Health Nutr 4(2B)::659-664

Burkhauser R, Cawley J, Beyond BMI (2008) The value of more accurate measures of fatness and obesity in social science research. J Health Econ 27:519-529

Carliner G (1980) Wages, earnings, and hours of first, second and third generation American males. Econ Inq 18:87-102

Cawley J (2004) The impact of obesity on wages. J Hum Resour 39:451-474

Cawley J, Han E, Norton E (2009) Obesity and labour market outcomes among legal immigrants to the United States from developing countries. Econ Hum Biol 7:153-164

Chiswick B (1978) The Effect of Americanization on the earnings of foreign-born men. J of Polit Econ 86:897-921

Chiswick B (1980) The earnings of white and coloured male immigrants in Britain. Econ 47:81-87

Chiswick B, Miller P (2002) Immigrant earnings: Language skills, linguistic concentrations and the business cycle. J of Popul Econ 15:31-57

Choi J (2011) Prevalence of overweight and obesity among US immigrants: Results of the 2003 New Immigrant Survey. J of Immigr Minority Health. doi:10.1007/s10903-011-9560-8

Clark K, Lindley J (2005) Immigrant labour market assimilation and arrival efects: Evidence from the Labour Force Survey. SERP Working Paper \# 2005004.

Costa-Font J, Gil J (2004) Social interactions and the contemporaneous determinants of individuals' weight. Appl Econ 36:2253-2263

Doyle N, Hughes G, Wadensjo E (2006) Freedom of Movement of Workers from Central and Eastern Europe. Experiences in Ireland and Sweden. Sweden Institute for European Policy Studies (SIEPS).

Drewnowski A (2009) Obesity, diets, and social inequalities. Nutr Revs 67:S36-S39

Dustmann C, Glitz A, Vogel T (2010) Employment, wages and the economic cycle: Differences between immigrants and natives. Eur Econ Rev 54(1):1-27

Friedberg R (2000) You can't take it with you? Immigrant assimilation and the portability of human capital. J Hum Resour 18(2):221-251

Garcia J, Quintana-Domeque C (2006) Obesity, employment and wages in Europe. In: Bolin J, Cawley J (eds.). Adv Health Econ Health Serv Res 17:187-217

Goel MS, McCarthy EP, Phillips RS, Wee CC (2004) Obesity among U.S. immigrant subgroups by duration of residence. J Am Med Assoc 292(13)):2860-2867

Hao L, Kim J (2009) Immigration and the American obesity epidemic. Inter Migr Rev 43(2):237-262

Hatton T, Tani M (2003) Immigration and inter-regional mobility in the UK: 1982-2000. The Econ J 115(507): F342-F358

Hauck K, Hollingsworth B (2009) The impact of immigration, income and marriage on obesity. Paper presented at the 2009 Congress of the International Health Economics Assoc, Beijing, China

Health Protection Agency, Travel and Migrant Health Section (2008) Migrant workers from the EU Accession countries. http://www.hpa.org.uk/webc/HPAwebFile/HPAweb_C/1231243849907. Accessed 7 February 2012

Jasso G, Massey D, Rosenzweig M, Smith JP (2004) Immigrant health - selectivity and acculturation. In: Anderson N, Iulatao R, Cohen B (eds) Critical Perspectives on Racial and Ethnic Differences in Health in Later Life. National Research Council of the National Academies, Washington DC, pp 227-268

Johansson E, Bokckerman P, Kiiskinen U, Heliovaarta M (2009) Obesity and labour market success in Finland: The difference between having a high BMI and being fat. Econ Hum Biol 7:36-45

Kaplan M, Huguet N, Newsom J, McFarland B (2004) The association between length of residence and obesity among Hispanic immigrants. J of Prev Med 27(4):323-326

Kaushal N (2009) Adversities of acculturation prevalence of obesity among immigrants. Health Econ 18:291-303

Kennedy S, McDonald J, Biddle N (2006) The healthy immigrant effect and immigrant selection: evidence from four countries. SEDAP research paper No.164. http://socserv.mcmaster.ca/sedap/p/sedap164.pdf Accessed 19 May 2012

Kirchengast S, Schobert E (2006) To be an immigrant: A risk factor for developing overweight and obesity during childhood and adolescence? J Biosoc Sci 38:695-705

Klarenback PR, Chuck A, Jacobs P (2006) Population-based analysis of obesity and workforce participation. Obesity 14(5):920-927 
Lundborg P, Bolin K, Höjgård S, Lindgren B (2007) Obesity and occupational attainment among the 50+ of Europe. In: Bolin K, Cawley J (eds) Advances in health economics and health services research, The Economics of Obesity, 17th edn. Elsevier, Amsterdam, pp 221-254

McDonald J, Kennedy S (2005) Is migration to Canada associated with unhealthy weight gain? Overweight and obesity among Canada's immigrants. Soc Sci Med 61:2469-2481

Morris S (2006) Body mass index and occupational attainment. J Health Econ 25:34-364

Morris S (2007) The impact of obesity on employment. Labour Econ 14:413-433

OECD (2011) Statistics from A to Z: Migration: Inflows of Foreign Population into OECD Countries. http://www.oecd. org/document/0,3746,en_2649_201185_46462759_1_1_1_1,00.html. Accessed 18 May 2012

Pagán J, Dávila A (1997) Obesity, occupational attainment, and earnings. Soc Sci Q 78:756-770

Park J, Myers D, Kao D, Min S (2009) Immigrant obesity and unhealthy assimilation: Alternative estimates of convergence or divergence, 1995-2005. Soc Sci Med 69:1625-1633

Rovelli R, Bruno R (2008) Labor Market Policies, Institutions and Employment Rates in the EU-27. IZA DP 3502.

Romero-Corral A, Montori V, Somers V, Korinek J, Thomas R, Allison T, Mookadam F, Lopez-Jimenez F (2006) Association of bodyweight with total mortality and with cardiovascular events in coronary artery disease: a systematic review of cohort studies. Lancet 368(9536):666-678

Salt J, Miller J (2006) Foreign labour in the United Kingdom: Current patterns and trends. Labour Mark Trends 10:335-355

Sapir A (2006) Globalization and the reform of European social models. J of Common Mark Stud 44(2):369-390

Shields MA, Wheatley Price S (2002) The English language fluency and occupational success of ethnic minority immigrant men living in English metropolitan areas. J of Popul Econ 15:137-156

Sobal J (2004) Sociological analysis of the stigmatization of obesity. In: German J, Williams L (eds) A Sociology of Food and Nutrition: The Social Appetite, 2nd edn. Melbourne, John Wiley, pp 83-402

Sorlie P, Backlund E, Johnson N, Rogot E (1993) Mortality by Hispanic status in the United States. J Am Med Assoc 270(20):2464-2468

Sriskandarajah D (2004) EU Enlargement and Labour Migration: An Ippr Factfile. http://ippr.org/search/112?at[0] $=$ Miranda+Grell\&siteid=ippr. Accessed 30 January 2012

Thomas D, Frankenberg E (2000) The Measurement and interpretation of health in social surveys. RAND Working Paper DRU-2550-NIA

Trejo S (1997) Why do Mexican Americans earn low wages? J of Polit Econ 105(6):1235-1268

Tremblay MS, Perez CE, Ardern Cl, Bryan SN, Katzmarzyk PT (2005) Obesity, overweight and ethnicity. Health Rep 16(4):23-36, Statistics Canada, Catalogue 82-003

Wada R, Tekin E (2010) Body composition and wages. Econ Hum Biol 8:242-254

Wheatley Price S (2001) The employment adjustment of male immigrants in England. J of Popul Econ 14(1):193-220

Zhang L, Rashad I (2008) Obesity and time preference: the health consequences of discounting the future. J Biosoc Sci 40:97-113

doi:10.1186/2193-9039-1-2

Cite this article as: Averett et al:: Immigration, obesity and labor market outcomes in the UK. IZA Journal of Migration 2012 1:2.

\section{Submit your manuscript to a SpringerOpen ${ }^{\circ}$ journal and benefit from:}

- Convenient online submission

- Rigorous peer review

- Immediate publication on acceptance

- Open access: articles freely available online

- High visibility within the field

Retaining the copyright to your article

Submit your next manuscript at $\boldsymbol{\sim}$ springeropen.com 